THEATER OF THE PEOPLE 
THIS PAGE INTENTIONALLY LEFT BLANK 


\section{THEATER of the PEOPLE SPECTATORS and SOCIETY in ANCIENT ATHENS}

DAVID KAWALKO ROSELLI 
This book has been supported by an endowment dedicated to classics and the ancient world and funded by the Areté Foundation; the Gladys Krieble Delmas Foundation; the Dougherty Foundation; the James R. Dougherty, Jr. Foundation; the Rachael and

Ben Vaughan Foundation; and the National Endowment for the Humanities.

Copyright $\odot$ 20II by the University of Texas Press

All rights reserved

Printed in the United States of America

First edition, 20II

Requests for permission to reproduce material from this work should be sent to:

Permissions

University of Texas Press

P.O. Box 7819

Austin, TX 78713-7819

www.utexas.edu/utpress/about/bpermission.html

(ळ) The paper used in this book meets the minimum requirements of ANSI/NISO Z39.48-I992 (RI997) (Permanence of Paper).

LIBRARY OF CONGRESS CATALOGING-IN-PUBLICATION DATA

Roselli, David Kawalko.

Theater of the people : spectators and society in ancient Athens /

David Kawalko Roselli. — Ist ed.

p. $\quad \mathrm{cm}$.

Includes bibliographical references and index.

ISBN 978-0-292-72394-8 (cloth : alk. paper)

ISBN 978-0-292-73469-2 (E-book)

I. Theater-Greece-Athens-History-To 500. 2. Theater audiences-Greece-

History-To I500. 3. Theater and society-Greece-Athens-History-To I500. I. Title.

$$
\begin{gathered}
\text { PA3203.R57 2OII } \\
792.0938^{\prime} 5-\mathrm{dc2} 2 \\
2010052680
\end{gathered}
$$

